\title{
Fixing the Poor: Eugenic Sterilization and Child Welfare in the Twentieth Century
}

Review Number: 2283

Publish date: Thursday, 27 September, 2018

Author: Molly Ladd-Taylor

ISBN: 9781421423722

Date of Publication: 2017

Price: $£ 28.00$

Pages: 304pp.

Publisher: John Hopkins University Press

Publisher url: https://jhupbooks.press.jhu.edu/content/fixing-poor

Place of Publication: Baltimore

Reviewer: Marius Turda

The history of eugenics continues to provide new and challenging ways to interpret the some of the major developments in social policy and social work during the 20th century, from child welfare, public health, and family planning, to the institutionalisation of disabled persons and the treatment of mentally ill. In recent years, a number of scholars have increasingly questioned certain readings of the eugenic policies of the past which even when not dealing directly with Nazi Germany continued nevertheless to prioritise race as the essential category of the eugenic agenda. What began as a breakaway from the strictures of a historiographic tradition glued to National Socialism has now firmly established itself within the mainstream of the scholarship on the history of eugenics. But current topics and avenues of study are inevitably framed by the past scholarship, which sets up challenges and assumptions to either refine or refute. Sterilization is one such topic requiring re-examination, particularly the underlying assumption that what drove state and public support for this method of population management and control was eugenic notions of racial protectionism. This is certainly one seminal aspect in the history of sterilization, but there are other aspects which are not defined eugenically but socially and economically, alongside a complex system of institutional factors and family decisions. These aspects together have consistently defined sterilization as modern society's most effective agent in controlling reproduction.

The importance of sterilization therefore cannot be overstated. Again and again, we hear stories of coerced sterilization that had happened in American hospitals or, more recently, in American prisons. Not surprisingly, then, sterilization occupies a central place in the new histories of eugenics, particularly those written about North America, as demonstrated by the work of a host of scholars including as Ian R.

Dowbiggin, Paul Lombardo, Erika Dyck, Randall Hansen and Desmond King, and Adam Cohen. They all provide, in different ways, a healthy re-evaluation, carefully grounded in archival research, of the history of sterilization in the 20th century.

Molly Ladd-Taylor's study of the history of sterilization in Minnesota represents the latest example of this growing body of scholarship. It is a work of commanding erudition and solid archival research. The major contribution of this study is the way in which its author looks at and, correspondingly, interprets and evaluates the convoluted trajectory of sterilization in Minnesota, from its origins in the 1880 s to its official 
termination in the 1970s. Importantly, her focus is not on eugenic discourses of racial improvement but on social and child welfare policies, particularly those aimed at the 'feebleminded' and the 'dependent poor'. She insists that the categorisation often imposed by scholars on the history of sterilization records does not always reflect the reasons behind such practice. Most people assume a direct connection between eugenic ideas of racial betterment and sterilization but the evidence from Minnesota points to other reasons.

Voluntary sterilization in Minnesota was driven more by economic, social and institutional reasons than eugenic and racial arguments. This is one of the major strengths of Ladd-Taylor's approach: her emphasis on the multifactorial nature of sterilization decisions and her repeated warnings against the risk of oversimplification in interpreting sterilizations in Minnesota as driven by eugenic concerns.

Most of those sterilized in Minnesota were women, described as 'feebleminded', as children in need of protection and, overall, as poor, and thus unable to provide for their own children. The connections between feeblemindedness, childhood and poverty are particularly revealing and are crucial to the author's claim that in Minnesota "eugenic sterilization was never only about "race betterment" or social engineering; from the beginning, state sterilization policies were rooted in a chronically underfunded and locally variable welfare system that pathologized persistent poverty and disparaged welfare-dependent individuals as mentally incompetent and underserving'. (pp. 225-6).

In chapter one Ladd-Taylor focuses on child welfare and disability, and how a concern with the growing number of 'feebleminded' (mostly women) at the end of the 19th century contributed significantly to a twopronged approach to the rationalisation of eugenics as a welfare strategy by the late 1910s. On the one hand, there was a drive towards the institutionalisation and segregation of 'defectives', promoted by eugenicminded officials such as Arthur Custis Rogers, the superintendent of the Minnesota School for the Feebleminded and director of the Faribault School for the Feebleminded (between 1885 and 1917). On the other, tellingly, there was still significant legal and professional reticence from Minnesota's child welfare organisations regarding the introduction of a sterilization law. In shedding light on these foundations LaddTaylor pays equal attention to some of the women affected by such ideas and practices, pausing to unravel the tangled roots of the connections between child welfare responsibilities, local relief practices and financial constraints.

By the early 1920s, eugenics was becoming increasingly incorporated in Minnesota's welfare programmes. The establishment of the Minnesota Eugenics Society in 1923, due to the efforts of physician Charles Fremont Dight, and, notably, the passing of the sterilization law on 8 April 1925, contributed greatly to an intensification of eugenic rhetoric in Minnesota's institutions, although one of the main architects of Minnesota's sterilization programme, Mildred Thomson, who in 1924 became director of Minnesota's Department for the Feeble-Minded, was rarely in support of eugenics. Chapter two moves to discuss the impact of the sterilization law. As Ladd-Taylor shows, Dight's efforts notwithstanding, in Minnesota the sterilization law targeted only institutionalised 'feebleminded and insane persons'. It required the expertise and approval of three experts: superintendent of the School for the Feebleminded, a physician and a psychologist, and, importantly, the consent of the patient's family or spouse. Serious frictions developed between staunch supporters of eugenic sterilization such as Dight and reformers such as Thomson and some members of the State Board of Control, the legal guardian of disadvantaged children. Although a certain consensus existed between child welfare officials, institution superintendents, social workers and eugenicists regarding the importance of sterilization as a birth control method for poor young women there was also opposition (and not only from the Catholic Church) to expanding the remit of the sterilization law to include everyone deemed 'unfit' or 'degenerate'. Ladd-Taylor explains the disagreements between these officials with wonderful clarity.

Chapter three provides a detailed discussion of who was described as 'feebleminded', according to which criteria, considering that those thus defined were then sterilized. Once again the analysis moves from theory to practice, and Ladd-Taylor illustrates her argument with case studies from the State Institute for Feebleminded in Faribault, where most sterilizations performed under the 1925 law took place. The majority of those sterilized were women but men designated as 'defective delinquent' also incurred sterilization. 
Ladd-Taylor convincingly demolishes the argument about the eugenic motivation behind those sterilizations authorised by a judge. In Minnesota, the judge's decision to permit sterilization of the 'feebleminded' was based less on 'abstract eugenic theories about human heredity' and more on 'practical economic and social concerns’ (p. 116).

Taking these details into account it is, perhaps, not surprising that Minnesota's sterilization programme differs from those of other US states. In chapter four, Ladd-Taylor places her case-study on the US sterilization map. She compares similarities and differences between Minnesota and other, better known, states such as Indiana, California, North Carolina and Virginia, which enacted and carried out sterilizations in the 20th century. The statutory provision for consent was one defining element of Minnesota's sterilization programme, and this requirement was taken seriously by Minnesota officials. The role of the family is highlighted here, and the coercive gaze of the state questioned. Yet, as Ladd-Taylor rightly points out, consent had multiple meanings and it should not be assumed that consent was always given freely or that, indeed, was given at all (although it was recorded by officials). Neither should we assume that individuals did not resist sterilization, and a number of examples, of both men and women, are provided to this effect. The descriptions of the individual cases are clear, not an easy task considering the sensitive material it contains, and the discussion is often illuminating. This, again, illustrates how different local contexts have their own stories, and that there is no single, overarching narrative of sterilization that can be applied across the country.

A similar concern for complex answers marks Ladd-Taylor's reflections on sterilization and welfare during the 1930s and 1940s offered in chapter five. The power of the state and the influence of the welfare authorities may have increased during the depression and wartime but so did forms of resistance and reform. Although sterilization continued to be used in institutions and notions of 'feeblemindedness' did not disappear from the thinking of welfare and child care officials, the end of the Second World War brought Minnesota's sterilization programme under renewed scrutiny. As expected, much of the growing disapproval of eugenics was connected less to new theories of heredity provided by genetics or to the crimes perpetuated in the name of racial hygiene by the Nazi regime and more to a rethinking of the relationship between poverty and welfare that characterised post-war America.

The book concludes with an examination of the changes and continuities in Minnesota's sterilization programme, alongside the gradual transformation of notions of mental health and disability; feeblemindedness was less talked about, making way for the idea of mental retardation and culminating in the creation of the Minneapolis Association of Parents and Friends of Mentally Retarded in 1946. This new impetus for mental health reform was paralleled by a broader reconsideration of the role of welfare institutions and a new political realignment, which promoted and militated against biological racism and for civil rights. But eugenics and eugenicists did not suddenly disappear. Harvard geneticist Sheldon Reed became director of the University of Minnesota's Institute for Human Genetics, established and named after Dight in 1941. Whilst a strong promoter of civil rights, Reed - who was also a member of the American Eugenics Society and of the Human Betterment Association of America - was nevertheless a supporter of sterilization, particularly of those poor and disabled, as outlined in his 1965 book Mental Retardation: A Family Study. 
As well as the wider questions of how to re-think the post-war history of eugenics and sterilization in Minnesota, Ladd-Taylor also engages directly with mental welfare aspects of this history. This is well illustrated by the activities of David J. Vail who became director of medical services at the Minnesota Department of Public Welfare in the early 1960s. He was critical of outdated notions of mental deficiency and advocated a complete transformation of hospital practices in Minnesota, which he deemed barbaric and inhumane. Sterilizations continued to be performed, however, on both women and men, until 1962. It took another 15 years for the Minnesota legislature to revise the sterilization law and provide greater protection for the 'mentally retarded'. Half a century of official sterilization had come to an end in Minnesota. During this time 2,350 individuals were sterilized, out of which 519 were men and 1,831 were women. About 18 per cent were deemed mentally ill and 82 per cent were considered mentally deficient.

Official eugenics has been discredited, but poverty and dependency continue to shape state welfare policies as much as disability and gender. Worryingly, commitment, institutionalisation and sterilization are still regarded as strategies to deal with groups and individuals in society who are considered to be a 'problem' or a 'menace' and thus relentlessly pursued by hostile welfare policies. As Ladd-Taylor notes at the end of her study, 'prisons today serve many of the same functions as public institutions for the insane and feebleminded during the heyday of eugenics: they break up families, reduce the number of babies born to the "defective, dependent, and delinquent classes", and promise to protect society from danger by keeping people considered dark, oversexed, and menacing "out of sight and out of mind"” (pp. 224-5). Though we may argue about the extent of this claim, this is a sombre warning, to be taken seriously.

This is a book that deserves to be read widely, and not only by historians of eugenics. Not only it is informative about a less-studied chapter in the history of sterilization in the USA but it also sets high standards of scholarship and establishes a point of reference for any future discussion of sterilization in the USA and elsewhere. No social scientist interested in the history of institutionalised care and no historian interested in social welfare will be able to dispense with it.

The author is happy to accept this review and does not wish to comment further.

\section{Other reviews:}

$\mathrm{H}-\mathrm{Net}$

https://networks.h-net.org/node/4189/reviews/1925195/caldwell-ladd-taylor-fixing-poor-eugenicsterilization-and-child [2]

Source URL:https://reviews.history.ac.uk/review/2283

\section{Links}

[1] https://reviews.history.ac.uk/item/297401 [2] https://networks.hnet.org/node/4189/reviews/1925195/caldwell-ladd-taylor-fixing-poor-eugenic-sterilization-and-child 